\title{
Survey and Identification of Common Weeds Associated with Rice and Vegetable Production in Rosario, La Union, Philippines
}

\author{
Angelina T. Gonzales \\ College of Agriculture, Cagayan State University, Lal-lo Campus, Philippines
}

Copyright $(2017$ by authors, all rights reserved. Authors agree that this article remains permanently open access under the terms of the Creative Commons Attribution License 4.0 International License

\begin{abstract}
A preliminary survey, collection and identification of weeds in rice and vegetable production areas in Rosario, La Union, Philippines were done to identify most common and prevalent weeds associated with rice and vegetable. Fields surveys were done according to the quantitative survey method using $1.0 \mathrm{~m} \times 1.0 \mathrm{~m}$ size quadrat with 20 samples from each field. Weeds present in each field were identified and the data were used to calculate frequency and relative dominance values for each species. A total of 45 species of weeds were collected and identified. Dominant weeds in vegetable and rice production during wet season were Digitaria sp., F. littoralis, A. conyzoides, C. pubescens and D. aegyptum. However, dominant weeds in rice production area were: Digitaria sp. and Dactyloctenium aegyptium; while Chloris sp. and Fimbristylis littoralis Gaudich, Centrosema pubescens Benth and Cyperus killingia and Cyperus rotundus L. and Dactyloctenium aegyptium at vegetable area. Based on the survey annuals were more dominant than perennial. More survey work is needed on a regular basis to identify possible problematic weed and weed population shifts and direct research toward new or improved control measures.
\end{abstract}

Keywords Quadrat Method, Dominant Weed, Prevalent Weed

\section{Introduction}

The annual global economic loss caused by weeds has been estimated at more than $\$ 100$ billion U.S. dollars [2]. Weeds, considered as obnoxious plants, are one of the pests associated with any agriculture endeavor and compete with rice and vegetable plants for sunlight, space, water, and nutrients in the soil. Weeds may also act as alternate hosts to insect pests and pathogens attacking vegetable and rice production areas. Research indicated that, worldwide, over
$10 \%$ of agricultural production is lost as a result of crop weed competition for the resources light, water and nutrients [14]. According to Akobundu, I.O. [1] when weeds are left uncontrolled, yield losses range from 20-100\%, depending upon the crop and its environment. The author reported loss estimates of $5 \%$ in developed countries, $10 \%$ in the less developed countries and $25 \%$ in the least developed countries. This clearly indicates problems associated with weed control in tropical crops. When weeds are left uncontrolled, yield losses range from 20-100\% depending upon the crop and its environment.

Van Heemst, H.D.J. [19] ranked different crops according to their competitiveness with respect to uncontrolled weeds, based on extensive literature data. Wheat appeared to be the most competitive crop, followed by peas, potatoes, soybean, sugarcane, maize, sorghum and transplanted rice (yield loss less than 50\%). Many tropical crops like groundnut, cassava, upland rice, yam and mung bean were less competitive with yield losses ranging from 60 to $100 \%$. Globally, weed is a notorious pest for rice causing serious yield reduction in rice production with annual worldwide rice yield loss by weed is 9.5\% [15] and 10-35\% in Malaysia [10].

Rice and vegetable productions are the major activity in Institute of Agriculture Nagtagaan Campus. These two crops are grown almost anywhere in the Philippines as staple food and source of income, respectively. So far, no related study has been conducted regarding the occurrence, distribution and identification of common weeds associated with rice and vegetable production in Region 1, specifically in La Union 2, hence this study.

Surveys are commonly used to characterize weed populations in cropping systems [18]. Therefore, to development an effective weed management program, a thorough survey is necessary to address the current weed problems in the field. In addition, survey information is absolutely important in building target oriented research programs. The information generated in this research is therefore important and can be very useful in predicting the 
invasive potential of weeds biotypes over time and may provide insight for effective control strategies. Therefore this survey was conducted: (1) to identify and classify common weeds associated with rice and vegetable production at Rosario, La Union during wet season.

\section{Materials and Methods}

\subsection{Survey, Collection and Identification of Weed Samples}

The surveys were conducted in some selected rice and vegetable production areas in the Institute of Agriculture Nagtagaan Campus Rosario, La Union, Philippines to identify and evaluate the major weed species associated with established production areas during wet season of 2014 using quadrat method. A quadrat measuring $1 \mathrm{~m} \times 1 \mathrm{~m}$ was randomly placed in weed- infested areas of each of the production areas. All weed species therein were uprooted, cleaned, and separately placed in plastic bags. There were five sampling sites per area taken during the wet season of 2014. The weed species were sorted, identified and classified according to Janiya, J. D. and K. Moody [8] and Moody, K et al., [13] and the data were summarized using descriptive and quantitative analyses.

\section{Results and Discussion}

Results of the survey on common weed species associated with rice and vegetable production areas during wet season yielded a total of 45 weed species in the surveyed areas. Dominant weeds associated with vegetable and rice plantation areas in Nagtagaan Campus, Rosario, La Union belong to grasses group and they were: Dactyloctenium aegyptium (L) Beauv., Digitaria sp., Eleusine indica (L) Gaertn., Trianthema portulacastrum L., Cyperus rotundus $L$. and Amaranthus spinosus L. for the wet season (Table 1). The study corroborates with the survey conducted by M. A. Hakim et al. [6] that Poaceae and Cyperaceae accounted together $55 \%$ of the species. Turki and Sheded [17] observed that seventy-one weed species of rice field belonging to 28 families were recorded in the Delta costal region in Egypt and the most represented families were Gramineae (28\%), Compositae (9\%), Cyperaceae (7\%), Malvaceae, Lythraceae, Chenopodiaceae, and Leguminosae (6\%) and Convolvulaceae (4\%).

In rice production area, Digitaria sp., Fimbristylis littoralis Auct. Non. Gaud and Imperata cylindrica (L) Beauv. were the more dominant weeds during the wet season (Table 2). Dominant weeds in vegetable area were Dactylloctenium aegyptium (L) Beauv, and Ipomoea triloba L., Eleusine indica L., Digitaria sp., and Chromolaeana odorata L. are common weeds in the wet season (Table 3 ). In mango-based rice production area, the more dominant weeds were Centrosema pubescen Benth, Ageratum conyzoides L., Digitaria sp. and Cyperus kyllingia Endl. during wet season. Dominant weeds were those species which occurred in relatively greater number than the other species.

Table 1. Common weeds identified on rice and vegetable production areas Rosario, La Union, wet season, (2014).

\begin{tabular}{|c|c|c|}
\hline Common Name & Number & Scientific Name \\
\hline Crowfoot grass & 130 & $\begin{array}{c}\text { Dactyloctenium aegyptium (L) } \\
\text { Beauv }\end{array}$ \\
\hline Large crab grass & 99 & Digitaria spp. \\
\hline Goose grass & 46 & Eleusine indica (L) Gaertn \\
\hline Malvastrum & 32 & $\begin{array}{l}\text { Malvastrum coromandelianum } \\
\text { (L.) Garcke }\end{array}$ \\
\hline Common grass & 25 & Trianthema portulacastrum $L$. \\
\hline Jungle rice & 22 & Echinochloa colona (L.) Link. \\
\hline Bermuda grass & 22 & Cynodon dactylon (L) Pers, \\
\hline Saluyot & 15 & Corchorus olitorius L. \\
\hline Purple nutsedge & 14 & Cyperus rotundus $\mathrm{L}$. \\
\hline Spiny amaranth & 13 & Amaranthus spinosus $\mathrm{L}$. \\
\hline Giant sensitive plant & 12 & Mimosa invisa Mart. \\
\hline Makahiya & 10 & Mimosa pudica $\mathrm{L}$. \\
\hline Gatas-gatas & 7 & Euphorbia hirta L. \\
\hline Bulak-manok & 9 & Ageratum conyzoides L. \\
\hline Kandilaan & 9 & Cleome rutidosperma $\mathrm{DC}$ \\
\hline Colopogonium & 8 & Calopogonium mucunoides Desv. \\
\hline Lay flower & 5 & Commelina benghalensis $L$. \\
\hline Baging-baging & 4 & Ipomoea triloba $\mathrm{L}$. \\
\hline Centrosema & 2 & Centrosema pubescens Benth. \\
\hline Ulasiman & 2 & Portulaca oleracea $L$ \\
\hline
\end{tabular}

Table 2. Common weeds identified in five $1.0 \mathrm{~m} \times 1.0 \mathrm{~m}$ quadrat sampling sites at the rice production areas of Institute of Agriculture, Nagtagaan Campus, Rosario, La Union, wet season, (2014)

\begin{tabular}{|c|c|c|}
\hline Common Name & Number & Scientific Name \\
\hline Fimbristylis & 14 & $\begin{array}{l}\text { Fimbristylis littoralis Auct. Non } \\
\text { Gaud. }\end{array}$ \\
\hline Saka-saka & 13 & Digitaria sanguinalis (L.) Scop. \\
\hline Talahib & 10 & Imperata cylindrica (L.) Beauv. \\
\hline Crowfoot grass & 4 & $\begin{array}{c}\text { Dactyloctenium aegyptium (L.) } \\
\text { Beauv. }\end{array}$ \\
\hline Centrosema & 3 & Centrosema pubescens Benth. \\
\hline Goose grass & 3 & Eleusine indica (L.) Gaertn. \\
\hline Spindle top & 3 & Cleome rutidosperma DC. \\
\hline Devil weed & 2 & $\begin{array}{l}\text { Chromolaena odorata (L.) R.M. King } \\
\text { \& M. Robinson }\end{array}$ \\
\hline Cat's tail & 1 & Setaria geniculata (Lam) Beauv. \\
\hline Chloris & 1 & Chloris sp. \\
\hline
\end{tabular}


Table 3. Common weeds identified in five $1.0 \mathrm{~m}$ x $1.0 \mathrm{~m}$ quadrat sampling sites at the vegetable production areas of Institute of Agriculture, Nagtagaan Campus, Rosario, La Union, wet season, (2014)

\begin{tabular}{|c|c|c|}
\hline Common Name & Number & Scientific Name \\
\hline Goose grass & 21 & Eleusine indica Gaertn. \\
\hline Devil weed & 13 & $\begin{array}{c}\text { Chromolaena odorata } \\
\text { Cactyloctenium aegyptium (L) } \\
\text { Crowfoot grass }\end{array}$ \\
\hline Centrosema & 6 & Centrosema pubescens Benth \\
\hline Baging- baging & 5 & Ipomoea triloba L. \\
\hline Talahib & 5 & Imperata cylindrica \\
\hline Crab grass & 4 & Digitaria sanguinalis $($ L.) Scop. \\
\hline Makahiya & 4 & Mimosa pudica \\
\hline Chloris & 2 & Chloris sp. \\
\hline Palay-maya & 2 & Leptochloa sp. \\
\hline
\end{tabular}

Dactyloctenium aegyptium (L.) Beauv., Digitaria sp and Eleusine indica are the top three abundant weed species in rice and vegetable production in Rosaio, La Union. They are normally propagated through seeds and found in dry land field and plantation crops, and vegetables. In addition, Eleusine indica is an important weed in more than 60 countries in at least 46 crops and, in these, has the status of a serious weed in 30 countries and 27 crops. It was evaluated as the fifth worst weed in the world [12] and also rated fifth in a recent survey in Southeast Asia. Since they are commonly fast and rapidly spreading in the field, they must be closely monitored and be given attention before they cause menace in the area.

Most of the weeds found associated with the rice and vegetable production areas are weeds that emerge with or before the crop. Echinochloa crusgalli L., Amaranthus retroflexus $\mathrm{L}$, are considered most competitive and result in the greatest yield loss. In fact, the velvetleaf (Abutilon theophrasti Medic.) in corn (Zea mays L.), soybean [Glycine $\max$ (L.) Merr.], and dry bean (Phaseolus vulgaris L.) may be two (2) to 10 times higher for weeds emerging three (3) to four (4) weeks after the crop compared with those that emerge with the crop [4][15] [11]. Weeds that emerge later than the crop are much less competitive in terms of crop yield loss but still may be considered problematic if they influence crop harvest ability or reduce crop quality.

Weed density is an important factor in the control of weed species as explained by Wicks et al. [20]. He elaborated his claim by disclosing that where the average density of the species was $<9$ weeds $/ \mathrm{m} 2$ but some species were found greater density within the specific field. Similar results were reported by Uddin et al., [18] who found that the density of the most species increased compared to densities obtained from all of the fields. These results are also in accordance with the findings of Javaid et al [9] where they observed that the highest density and coverage was shown by the most common grass $C$. dactylon and $P$. hysterophorus $\mathrm{L}$ was second most densely populated weed species in grazing lands in Lahore.

Generally, most of common weeds identified in this survey were found in annual nature. This can be explained by the fact that seeds of annual weeds survive in unfavorable conditions and they have able to complete their life cycle from seed to seed in one season [16]. Moreover, the weeds which appeared common in rice and vegetable production areas with the highest mean field densities indicate that these weeds were the more difficult to control. So, these species should be carefully monitored.

Since weed succession and distribution patterns in rice fields are dynamic in nature, the composition of the weed flora may differ depending on location [13] [18]. The weed vegetation of a particular area is determined not only by the environment but also edaphic and biological factors that include soil structure, $\mathrm{pH}$, nutrients and moisture status, associated crops, weed control measures and field history especially in local geographical variation [6]. The information on the upto-date presence, composition, abundance, importance and ranking of weed species is needed to formulate appropriate weed management strategies to produce optimum yields of rice and vegetable.

\section{Summary and Conclusions}

Survey, collection and identification of weeds were done in the rice and vegetable production areas in La Union, Philippines during wet season of 2014. The results of the survey provide a quantitative comparison of the common weed species in vegetable and rice fields of Rosario, la Union, Philippines. A total of 45 species of weeds were collected and identified. Generally, dominant weeds observed during wet season were: Digitaria sp.; F. littoralis, $A$. conyzoides, $C$. pubescens and D. aegyptum. However, dominant weeds in rice production area were: Digitaria sp. and Dactyloctenium aegyptium; while Chloris $s p$ and Fimbristylis littoralis Gaudich, Centrosema pubescens Benth and Cyperus kyllingia and Cyperus rotundus L. and Dactyloctenium aegyotium at vegetable area. In conclusion, more survey work is needed on a regular basis to identify possible problematic weed and weed population shifts and direct research toward new or improved control measures.

\section{REFERENCES}

[1] AKOBUNDU, I.O. (1987). Weed Science in the tropics. Principles and practices. J. Wiley and Sons, New York

[2] APPLEBY AP, MULLER F, CARPY S. 2000. Weed Control. in Muller F, ed. Agrochemicals. New York: Wiley. pp 687707.

[3] BEGUM, M., A. S. JURAIMI, M. AZMI, S. R. SYED OMAR AND A. RAJAN (2008). Weed flora of different farm blocks in block-1 of muda rice granary in peninsular Malaysia. J. Biosci. 19: 33-43. 
[4] CARDINA J, REGNIER E, SPARROW D (1995). Velvetleaf (Abutilon theophrasti) competition and economic thresholds in conventional- and no-tillage corn (Zea mays). Weed Sci 43:81-87.

[5] DIELEMAN A, HAMILL AS, FOX GC, SWANTON CJ (1996). Decision rules for postemergence control of pigweed (Amaranthus spp.) in soybean (Glycine max). Weed Sci 44:126-132

[6] HAKIM, M. A., A. S JURAIMI, M. R. ISMAIL, M. M. HANAFI AND A. SELAMAT (2010). Distribution of weed population in the coastal rice growing area of Kehah in Peninsular Malaysia. J. Agron. 9: 9-16.

[7] M. A. HAKIM, A. S. JURAIMI, M. RAZI ISMAIL, M. M HANAFI AND A. SELAMAT. (2013). A Survey on weed diversity in coastal rice fields of Sebarang Perak in Peninsular Malaysia. The Journal of Animal \& Plant Sciences, 23(2): 2013, Page: 534-542

[8] JANIYA, J. D. AND K. MOODY (1983). Weed growth and yield of two rice crops grown in sequence in three rainfed locations in the Philippines. Philip. Agri. 66: 90-101.

[9] JAVAID, A., S. SHAFIQUE AND S. SHAFIQUE (2009). Invasion of noxious alien weed Parthenium hysterophorus 1 . in grazing lands of Lahore, Pakistan. The J. Anim. and Plant Sci. 19: 149- 153.

[10] KARIM, S. M. R., B. M. AZMI AND B. S. ISMAIL (2004). Weed problems and their management in rice fields of Malaysia: An overview. Weed Biol. Manan. 4:177-186

[11] KNEZEVIC SV, WEISE SF, SWANTON CJ (1994). Interference of redroot pigweed (Amaranthus retroflexus) in corn (Zea mays). Weed Sci 42:568-573
[12] MATIYAS M (1999). Major weed species in South Nations, Nationalities and Peoples Region. In: Reda F, Tanner DG (eds) Proceedings of the 5th annual conference of Ethiopian Weed Science Society (Arem 5), Addis Ababa, Ethiopia 5: 11-13

[13] MOODY, K. MUNROE, C.E., LUBIGAN, R.T. (2014). Major Weeds of the Philippines. Second Edition. UPLB, Laguna. Philippines

[14] PARKER, C. AND FRYER, J.D. (1975). Weed control problems causing major reductions in world food supply. FAO Plant Protection Bulletin 23(3/4),83 -95

[15] RABBANI, N., R. BAJWA AND A. JAVAID (2011). Interference of five problematic weed species with rice growth and yield. Afri. J. Biotech. 10:1854- 1862.

[16] SINGH, A., G. P. SHARMA AND A. S. RAGHUBANSHI (2008). Dynamics of the functional groups in the weed flora of dryland and irrigated agroecosystems in the Gangetic plains of India. Weed Biol. Manage. 8: 250-259.

[17] TURKI, Z. AND M. SHEDED (2002). Some observations on the weed flora of rice fields in the Nile Delta, Egypt. Feddes Repert. 113: 394-403.

[18] UDDIN, M. K., A. S. JURAIMI, M. R. ISMAIL AND J. T. BROSNAN (2010). Characterizing weed populations in different turfgrass sites throughout the klang valley of western peninsular Malaysia. Weed Technol. 24:173-181.

[19] VAN HEEMST, H.D.J. (1985). The influence of weed competition on crop yield. Agricultural Systems 18, 81 -93.

[20] WICKS, G. A., D. H. POPKEN, G. W. MAHNKEN, G. E. HANSON AND D. J. LYON (2003). Survey of winter wheat (Triticum aestivum) stubble fields sprayed with herbicides in 1998: Weed control. Weed Technol. 17:475-484. 